\title{
Bifid uvula
}

INSERM

\section{Source}

INSERM. (1999). Orphanet: an online rare disease and orphan drug data base. Bifid uvula. ORPHA:99771

Bifid uvula is a fissure type embryopathy affecting the uvula at the back of the soft palate. 